\title{
UM OLHAR CRIMINOLÓGICO SOBRE A REMIÇÃO DA PENA PELO ESTUDO: CRÍTICA À PREVENÇÃO ESPECIAL POSITIVA PELO TRABALHO
}

\section{Geovana Tavares de Mattos}

Graduanda do 9 período de direito da PUC/MG.

e-mail: geovanamattos@yahoo.com.br

RESUMO: O objetivo desta pesquisa foi demonstrar a possibilidade de admitir a remição da pena pelo estudo. O direito penal é um dos instrumentos de controle social utilizados pela classe hegemônica para se manter em sua posição dominante. Há uma seleção dos considerados criminalizados, realizada pelos ocupantes da citada classe, que não escolhem os pertencentes à mesma classe e os atos por eles cometidos para serem considerados criminosos, recaindo apenas sobre os grupos sociais subalternos. Assim, embora pessoas de todas as classes cometam delitos, praticamente apenas os pertencentes às classes inferiores são condenados. Portanto, a razão pela qual o Estado incentiva o trabalho dos condenados, mas não o faz em relação ao estudo é que a remição pelo trabalho, imbuída de pretensos propósitos ressocializadores, é utilizada para atingir pretensões capitalistas, tendo como funções reproduzir a desigualdade social, indispensável para a sobrevivência de uma sociedade que depende da exploração e submissão de um homem pelo outro, e de produzir reserva de mão-de-obra para a produção capitalista. Logo, a remição pela educação só não é aceita porque inibiria interesses da classe hegemônica, à medida que permitiria a qualificação dos internos, possibilitando-os almejar ascensão social. Concluiu-se, então, a imperiosa necessidade de admitir a remição da pena pelo estudo, que não tem apenas caráter de política criminal, possibilitando a concretização de um direito penal mais justo, fazendo com que a pena deixe de ser meio, para materializar os ideais capitalistas para garantir a efetiva ressocialização dos condenados.

PALAVRAS-CHAVE: Remição da pena; Prevenção especial positiva; Controle social. 


\section{A REMIÇÃO E A PREVENÇÃO ESPECIAL POSITIVA}

A doutrina buscou justificar o Direito Penal e a pena por ele imposta atribuindoIhe quatro finalidades preventivas, quais sejam, duas formas de prevenção geral, positiva e negativa, e duas formas de prevenção especial, também positiva e negativa.

Nesse estudo nos interessa apenas a prevenção especial positiva, pela qual se tentou legitimar a pena atribuindo-lhe uma função positiva de regenerar o condenado, sendo que para tanto imputou à pena a finalidade de ressocializar e reeducar os presos, visando uma melhor reinserção dos mesmos na sociedade.

Outrossim, o que se verifica é que a reinserção do condenado tem sido conduzida para duas formas: a "educação" para ser criminoso e a educação para ser bom preso, sendo que esta última se caracteriza pelo fato de o aprisionado ser uma mão de obra braçal, que se deixa explorar, seguindo, "disciplinadamente", as ordens que the são dadas, funcionando como mão de obra de reserva para o sistema de produção capitalista.

No entanto, nessa realidade é impossível a instituição carcerária cumprir as funções a que se propõe, tendo em vista que, como acertadamente ensina Alessandro Baratta:

As relações sociais e de poder da subcultura carcerária (...) não são mais do que a ampliação, em forma menos mistificada e mais 'pura', das características típicas da sociedade capitalista: são relações sociais baseadas no egoísmo e na violência ilegal, no interior das quais os indivíduos socialmente mais débeis são constrangidos a papéis de submissão e de exploração. (BARATTA, 1999a, pg. 180)

Os efeitos nocivos do encarceramento sobre os condenados impossibilitam qualquer tentativa de ressocialização, não havendo como se falar em reinserção e reeducação em um ambiente de exclusão e exploração ao qual os presos estão submetidos, características estas que exercem, na verdade, uma função marginalizadora, sendo um fator criminógeno de educação e promoção ao crime e ao trabalho praticamente escravo.

Desta forma, apesar da utópica função de reeducação, as instituições penais sempre treinaram os condenados para a disciplina das fábricas. Esta relação entre 
mercado de trabalho e o cárcere é perceptível se analisarmos que o Estado incentiva os presos a trabalhar, não acontecendo o mesmo em relação ao estudo. Conclui-se tal fato ao verificarmos que o art. 126 da Lei de Execução Penal dispõe: "O condenado que cumpre a pena em regime fechado ou semi-aberto poderá remir, pelo trabalho, parte do tempo de execução de pena." (grifo nosso)

Assim sendo, o Estado concede um benefício, qual seja, a redução da pena na proporção de 1 (um) dia a cada 3 (três) dias, para os presos que trabalharem. Todavia, aqueles que se disponibilizam a estudar, tornando-se, portanto, uma mão de obra qualificada, podendo aspirar uma elevação social, não têm o mesmo benefício.

Ora, não há dúvidas que a melhor forma de reinserir o condenado na sociedade é dando-lhe condições de estudar, o que promoveria a possibilidade de ambicionar ascensão econômica e social, realizando assim, de fato, a prevenção especial positiva.

Insta salientar ainda que, ao gerar uma qualificação nos condenados, permitirIhes-ia uma melhor readaptação, posto que teriam condições de concorrer com o grupo que tem acesso à educação, acarretando uma diminuição da reincidência, tendo em vista que teriam outra opção, senão voltar a delinqüir, única alternativa possível àqueles que, além de estigmatizados por uma condenação, ainda são desqualificados profissionalmente.

Nesse contexto, questionamos então o motivo pelo qual o Estado incentiva o trabalho, mas não incentiva a educação. Como será melhor explicitado nas análises realizadas no capítulo subseqüente, constatamos que a real função do sistema penitenciário é manter uma determinada forma de criminalização, preestabelecida pela classe dominante, visando inibir qualquer mobilidade social, temendo ter sua posição privilegiada substituída por outro grupo.

Por conseguinte, o que se observa é que o sistema penal não tem por fim permitir a emancipação dos condenados, concedendo-Ihes realmente reeducação para uma fácil reinserção na sociedade, mas tão somente produzir mão de obra braçal barata, facilmente explorada pela sociedade capitalista, que "tem necessidade de desempregados, que tem necessidade, por motivos ideológicos e econômicos, de uma marginalização criminal”.(BARATTA, 1999b, pg. 190) 


\section{A "ESCOLHA" DOS CRIMINALIZADOS}

A criminalidade não é um conceito ontológico, mas uma realidade construída de acordo com os interesses da classe social hegemônica, e, por isso, teremos diferentes criações desta criminalidade à medida que a realidade social é diferente.

Há, portanto, uma seleção não do fato delituoso, mas da pessoa do delinqüente, sendo que a seleção dos criminalizados parte de uma perspectiva das relações sociais de poder e de propriedade, sendo que aqueles detentores do poder decidem os que serão submetidos a tal poder.

Nesse contexto, vale lembrar da teria do labeling approach, trazida à baila por Alessandro Baratta, que acenou para o fato de que o poder de criminalização e o exercício deste poder estão ligados à estratificação e à estrutura antagônica da sociedade.(BARATTA, 1999c, p. 101-116)

Assim, o comportamento considerado como desviante, é aquele que uma parte da sociedade, obviamente aquela detentora dos meios de produção, o considerou como tal. Logo, cria-se um estereótipo do denominado criminoso, sendo tal posição ocupada pelos indivíduos que ocupam a escala social mais baixa, momento em que se percebe a natureza seletiva do processo de criminalização, concentrado na parcela mais "desfavorecida" da sociedade.

Tal "seleção" demonstra o caráter fragmentário do Direito Penal, refletindo e reproduzindo a realidade social em que é construído. Esta função do Direito Penal, e quando a exerce diz-se que está agindo como forma de controle social, é concretizada no momento em que impõe suas sanções àqueles previamente selecionados para sofrê-las, e dentre elas destacamos especialmente o cárcere, momento em que se está mantendo a escala vertical da sociedade.

Ora, a aplicação das sanções estigmatizantes aos escolhidos para serem os criminosos impedem sua ascensão social, conservando a realidade de desigual distribuição de recursos e benefícios, fruto e alimento da sociedade capitalista em que vivemos.

Ademais, como já citado, o direito, dentro do qual está presente o penal, não foi algo revelado ao homem, como supunha as antigas teorias nas quais estava presente 
uma noção religiosa, nem tampouco foi descoberto por sua razão, sendo produzido por uma parcela da sociedade que detém poder econômico capaz de assegurar-Ihe poder político, para fazer valer suas vontades, dentre as quais, evidentemente, está o interesse em se manter como classe dominante e favorecida, e, para isto, é necessário conter qualquer aspiração das classes desfavorecidas, sendo que ao Direito Penal é atribuído este papel.

Deste modo, como alguns indivíduos pertencentes à classe hegemônica definem quais crimes e quais pessoas serão perseguidas pelo Direito Penal, certo é que não entram nesse contexto os pertencentes ao grupo dominante, atacando apenas os interesses e direitos dos que ocupam posição social desvantajosa.

Tal fato é perceptível ao analisar que a maior parte dos delitos punidos pelo nosso Código Penal são aqueles cometidos contra o patrimônio, sendo notável que aqueles cuja condição econômica é precária, muitas vezes deplorável, são mais suscetíveis de cometê-los.

Nesse diapasão cumpre exemplificar o importante valor dado ao patrimônio em nosso direito. $\mathrm{O}$ art. 121 do Código Penal prevê que o homicídio será punido com a pena de 6 (seis) a 20 (vinte) anos de reclusão, sendo julgado pelo Tribunal do Júri. Entretanto, o crime de latrocínio, disposto no art. 157, §3으, segunda parte, do mesmo diploma legal, determina que a pena é de 20 (vinte) a 30 (trinta) anos de reclusão, estando tal delito previsto no título de crimes contra o patrimônio, sendo julgado pela justiça comum, e não pelo Tribunal do Júri, responsável apenas pelos crimes dolosos contra a vida. Constata-se, portanto, que nesse último caso, dá-se mais valor ao patrimônio do que à própria vida.

Observou-se que quanto maior a desigualdade presente numa sociedade, mais esta necessita de setores que exerçam um controle social, sendo que no presente estudo apenas analisamos tal função cumprida pelo Direito Penal, mas tal papel é exercido por diversos outros segmentos da sociedade. Isso ocorre porque em sociedades estratificadas, com grande disparidade na distribuição de recursos, há uma grande atuação dos que ocupam posições sociais vantajosas no sentido de evitarem uma mobilidade vertical e de sustentarem as relações de subordinação e de exploração do homem pelo homem. Para isso, selecionam dentre os pertencentes às classes 
inferiores aqueles que terão o status de criminoso, evitando, como já analisado, sua ascensão social, conservando a realidade existente.

Entretanto, cumpre analisar que a criminalidade não é um comportamento restrito àqueles que são efetivamente considerados como criminosos, como pretende difundir os responsáveis pela criação do estereótipo do criminoso, destinado a servir como "bode expiatório" utilizado para atender as conveniências políticas e o alarme social, mas, ao contrário, é um comportamento comum à maioria dos membros de nossa sociedade, de todos os estratos sociais.

Assim, o fato de ter uma condição social desfavorável não produz no indivíduo uma maior motivação para cometer ilícitos penais, mas há uma possibilidade maior que seus atos sejam definidos como desviantes, pelo fato de não pertencerem a uma classe social hegemônica, criadora dos que serão considerados delinqüentes.

Importante ainda ressaltar que como os "selecionados" para serem os criminosos pertencem à classe subalterna, a sua possibilidade de desenvolver habilidades, até mesmo para cometer crimes, é escassa, e, por isso, os eventuais delitos por eles cometidos são obras rudes, sendo, por isso, mais facilmente detectados, o que colabora ainda mais para concretizar o estereótipo criminal criado, tendo em vista que internalizam na sociedade arraigados preconceitos de classe, servindo ainda para encobrir outros inúmeros delitos cometidos pelas classes dominantes, que permanecem imunes ao processo de criminalização.

Desta forma, sabiamente Alessandro Baratta nos ensina que:

o Direito Penal tende a privilegiar os interesses das classes dominantes, e a imunizar do processo de criminalização comportamentos socialmente danosos típicos dos indivíduos a elas pertencentes, e ligados funcionalmente à existência de acumulação capitalista, e tende a dirigir o processo de criminalização, principalmente, para formas do desvio típicas das classes subalternas.(BARATTA, 1999d, p. 165)

O fato de o "filtro" dos tipos penais serem mais eficazes nos delitos próprios das classes sociais mais baixas pode ser facilmente averiguado quando avaliamos que os crimes cometidos por integrantes das classes sociais dominantes, que favorecem, portanto, a acumulação de capital, cuja danosidade se volta contra as classes inferiores, tem uma maior possibilidade de ficarem impunes, como é o caso dos crimes 
de "colarinho branco", dos crimes políticos e daqueles cometidos por grandes organizações criminosas (ciclo econômico da droga, seqüestros etc.).

Isto posto, comprova-se que o comportamento criminoso se estende a todas as classes sociais, havendo, inclusive, formas próprias das classes hegemônicas, cuja nocividade é, na maioria das vezes, mais grave que a criminalidade perseguida.

\section{A QUESTÃO DA EDUCAÇÃO}

Para explicar a seleção dos criminalizados várias teorias patológicas foram criadas com o intuito de uniformizar os comportamentos e sujeitos criminosos, e enunciavam que estes eram indivíduos possuidores de características biopsicológicas anormais em relação aos demais indivíduos.

Um dos precursores destas teorias foi Cesare Lombroso, que definiu o delinqüente como um europeu que não havia completado seu desenvolvimento embriofetal, considerando assim que os criminalizados pertenciam a um grupo biologicamente diferente e inferior, resultando em um indivíduo semelhante ao selvagem colonizado, parecendo fisicamente com o indígena ou o negro. (ZAFFARONI; BATISTA, 2003a, p. 569-581)

Desta forma, estas teorias patológicas foram também responsáveis pela função conservadora em face do sistema penal, uma vez que apontavam não para as causas do delito, mas para os motivos da criminalização, solidificando o estereótipo criminal à medida que a seleção da população delinqüente coincidia com a seleção biológica.

Ora, qualquer teoria nesse sentido realizada atualmente apontaria para os pobres e negros, pertencentes às classes subalternas, que são os "selecionados" como criminosos.

Porém, embora atualmente também haja teorias que tentem explicar biologicamente os fatores da criminalização, nos ateremos neste estudo àquelas que têm justificado a seleção dos criminalizados por características sociais e econômicas.

Tal fato pode ser exemplificado pelo Censo Nacional de Política Criminal e Penitenciária, que demonstra que quanto menor o índice de escolaridade, maior o número de presos. (CNPCP, 1995, p. 208). 
Em relação a esta matéria leciona Zafaronni:

Isto leva à conclusão pública de que a delinqüência se restringe aos segmentos subalternos da sociedade, e este conceito acaba assumido por equivocados pensamentos humanistas que afirmam serem a pobreza, a educação deficiente, etc., as causas do delito, quando, na realidade, são estas, junto ao próprio sistema penal, fatores condicionantes dos ilícitos desses segmentos sociais, mas, sobretudo, de sua criminalização, ao lado da qual se espalha, impune, todo o imenso oceano de ilícitos dos outros segmentos, que os cometem com menor rudeza ou mesmo com refinamento. (ZAFFARONI; BATISTA, 2003b, p. 48)

Destarte, o referido censo, assim como as citadas teorias patológicas tem 0 mesmo objetivo, de convencer toda a população, inclusive os pertencentes às posições sociais desvantajosas, de que aqueles que não pertencem às classes sociais dominantes, não tendo portanto as mesmas oportunidades, são mais suscetíveis de cometerem delitos. De tal modo tais pesquisas invertem o verdadeiro foco, induzindo a sociedade a acreditar que o fato de pertencer a um estrato social inferior motiva o indivíduo a praticar comportamentos desviantes, enquanto, na realidade, suas piores condições apenas determinam que seus comportamentos sejam selecionados como criminosos.

Desta maneira, as citadas teorias e pesquisas cumprem sua função de garantir a sustentação da classe dominante no poder, pois é uma forma de conter aqueles que pertencem às classes subalternas, evitando que compreendam que pertencem a uma classe oprimida, condenada justamente por suas condições sociais e econômicas desfavoráveis, condições estas que o grupo privilegiado não pretende que sejam alteradas.

Assim, o grupo hegemônico dificulta o acesso do grupo desprivilegiado à educação, pois esta proporciona o conhecimento da realidade, gerando revoltas e dificultando o domínio sobre os ocupantes deste grupo. Tal situação pode ser demonstrada pelo fato de que prisioneiros franceses que leram livros do Michael sobre a prisão, e consequentemente sobre a realidade que vivenciavam e da qual eram vítimas, fez com se rebelassem, como descreve o próprio em uma entrevista: "Mas há dois anos, na França, houve agitação em várias prisões, os detentos se revoltaram. Em 
duas dessas prisões os prisioneiros liam meu livro. De suas celas, alguns detentos gritavam o texto de meu livro para seus companheiros." (FOUCAULT, 2003, pg. 322)

Nesse contexto é que se adentrou na questão de que no Brasil o condenado pode remir sua pena pelo trabalho, mas não o pode fazer pelo estudo, de onde se conclui que as penitenciárias incentivam 0 trabalho dos encarcerados, mas não incentivam o estudo.

Tal fato, além de garantir mão-de-obra barata para o estado, questão que será analisada no próximo capítulo, é também uma das funções do Direito Penal como forma de controle social, sendo atribuído ao cárcere o papel de reproduzir as relações de disparidade existentes em nossa sociedade, com o intuito de manter a posição da classe dominante, e, para tanto, cria medidas eficazes contra estímulos à integração, educação e emancipação dos setores subalternos.

Desta maneira a remição no Brasil somente é concedida com base no trabalho e não com base no estudo, pois o cárcere não visa à melhoria nas condições do indivíduo, pois isto poderia ameaçar a posição daqueles que pertencem às classes dominantes.

Assim, não interessa à classe hegemônica que os pertencentes às classes inferiores tenham boas condições de estudo, o que os possibilitaria uma ascensão social, trazendo a tona uma concorrência que poderia fazer com que o atual grupo detentor do poder fosse substituído pelo grupo concorrente, que, se fosse devidamente instruído, aspiraria por melhores condições.

Ademais, o sistema capitalista é fomentado pela desigualdade, que permite a exploração e submissão daqueles que não tem poder àqueles que o detém, "vantagens" estas que a classe favorecida não pretende perder.

Deste modo, a classe que ocupa posição privilegiada, usa as instituições penais como uma forma de combater e neutralizar os grupos contrários, visando manter a funcionalidade do sistema econômico social que os favorece, e seus próprios interesses.

Logo, aqueles que pretendem estudar para obter melhores condições na vida, se tornar uma mão de obra qualificada, podendo almejar por progredir na escala social, a estes não se pode conceder a remição, pois estão indo contra os interesses que o 
grupo hegemônico formulou para eles, quais sejam, de se manterem uma mão de obra apenas braçal, contidos na posição em que ocupam, sendo facilmente explorados.

Percebe-se, portanto, que a questão do controle social exercido pelo Direito Penal está ligada não apenas à desigualdade na distribuição de renda, mas também à disparidade que resulta das relações sociais de produção.

\section{O TRABALHO NAS PRISÕES}

Nos capítulos anteriores verificou-se que o sistema penal não apenas escolhe os indivíduos que irão sofrer suas sanções, como também reproduz em suas instituições, principalmente no cárcere, a desigualdade existente em nossa realidade social.

Nesse capítulo analisou-se que tais funções destinadas ao Direito Penal vão além de funcionar como forma de conter a mobilidade social, desempenhando ainda o papel de adaptar os presos à "disciplina da fábrica" garantindo mão-de-obra barata, essencial para manter o desenvolvimento capitalista.

Nesse contexto, vale lembrar que o cárcere nasceu junto com a sociedade capitalista, acompanhando sua história. E está ligado, portanto, conforme já mencionado, à relação de desigualdade por esta gerada, não apenas a social, mas de detenção dos meios de produção.

Deste modo, as nossas instituições carcerárias, imbuídas de um suposto caráter ressocializador, incentivam e exploram a mão de obra dos presos, acirrando a desigualdade social. Visam garantir as exigências necessárias para sobrevivência do sistema capitalista, que depende da existência destas relações de disparidade para manter as relações de subordinação, imprescindível para que as classes excluídas se deixem explorar.

Portanto, a classe hegemônica utiliza o sistema penal não apenas para conter a classe subalterna, valendo-se do mesmo ainda para garantir seus interesses como grupo detentor dos meios de produção.

Logo, as instituições penais passaram a tornar os encarcerados funcionais para as indústrias, não mais ocorrendo como na revolução mercantil na qual selecionavam 
os inimigos para eliminá-los, tendo agora como principal propósito domesticar para explorar.

A possibilidade de lucros era um motivo decisivo para a instituição das casas de correção. Henelius, um de seus defensores mais ativos, argumentava em favor da substituição da pena de morte pelo confinamento, dizendo que a execução pode ser mais barata de um ponto de vista imediato, mas que a longo prazo era improdutiva e até mesmo mais cara, de modo que a nova forma de punição iria forçar os delinqüentes a trabalhar para o Estado. (RUSCHE; KIRCHHEIMIER, 1999b, p. 71)

Conseqüentemente os presos passaram a ser educados para a disciplina das fábricas, tornando-se a força de trabalho que o Estado melhor podia comandar, pois estavam sempre sob sua vigilância e supervisão, mantendo sobre os presos um controle total, sendo a rotina dos condenados regulada precisamente.

Essa realidade é demonstrada por Foucault ao escrever sobre o panoptismo:

Esse espaço fechado, recortado, vigiado em todos os seus pontos, onde os indivíduos estão inseridos num lugar fixo, onde os menores movimentos são controlados, onde todos os acontecimentos são registrados, onde um trabalho ininterrupto de escrita liga o centro e a periferia, onde o poder é exercido sem divisão, segundo uma figura hierárquica contínua, onde cada indivíduo é constantemente localizado, examinado e distribuído entre os vivos, os doentes e os mortos - isso tudo constitui um modelo compacto do dispositivo disciplinar.(FOUCAULT, 2000, p. 163)

O principal efeito do panóptico é o detento se conscientizar da possibilidade de estar sendo vigiado a qualquer momento, embora nem sempre o estivesse efetivamente. Assim, se torna evidente a relação entre cárcere e fábrica, tendo o sistema penal contribuído para o treinamento de mão-de-obra para as indústrias, se tornando um verdadeiro centro de produção.

Neste aspecto, cumpre ressaltar que não há, portanto, qualquer interesse em incentivar a educação dos presos, porque, como já analisado, a classe detentora do poder teme ter sua posição privilegiada substituída, caso a classe subalterna se qualifique a ponto de almejar uma ascensão social, a dois pelo fato de que é necessário manter a diversidade na distribuição de renda e dos meios de produção. $O$ 
desenvolvimento do capitalismo depende dessa desigualdade, capaz de manter as relações de submissão e de exploração.

Assim, a política penitenciária é dirigida de maneira a refletir as desigualdades da nossa realidade social, medida indispensável para manter o lucro capitalista.

\section{A PRIVATIZAÇÃO DAS PRISÕES}

Neste contexto de tentativa de incentivar a educação dos condenados, criticando a atual disciplina de fábrica dada aos encarcerados, não há como deixar de analisar um importante assunto em voga na atualidade: privatização das prisões.

As experiências com privatização das prisões privadas foram iniciadas nos Estados Unidos a partir da década de 80, tendo se tornado objeto de discussões mais amplas em nosso país apenas nos últimos anos. Tanto que há apenas duas penitenciárias nas quais há participação privada, fato que ocorreu recentemente, na Penitenciária Industrial de Regional do Cariri, no Ceará e na Penitenciária Industrial de Guarapuava, no Paraná. (NETO, [200_], p. 4)

Os defensores da privatização das cadeias alegam que esta seria uma forma de melhorar o sistema penitenciário, uma vez que já é sabido que as penitenciárias além de não recuperar os presos ainda os tornam mais propensos a delinqüir.

Entretanto, se nos presídios administrados pelo Estado, os quais não deveriam ter como objetivo auferir lucro, não há incentivo à educação dos detentos, uma vez que as instituições penais tem sido dirigidas com o propósito de manter as desigualdades e de treinar mão-de-obra para as indústrias. Tal fato será ainda mais acentuado nas prisões privadas, nas quais o caráter econômico está ainda mais evidente.

Não há como admitir que a iniciativa privada, que visa o lucro, tenha o direito de ter sobre os condenados o poder da guarda, visto que tais instituições têm como pressuposto a exploração da mão-de-obra dos detentos, tendo em vista que é a forma de reembolsar os gastos com a construção dos presídios e permitir a acumulação de capital.

Assim, se já é nocivo o fato de o Direito Penal ser exercido como meio de controle social, sob o comando do grupo detentor dos meios de produção, que, como já 
visto, preestabelece quem será considerado criminoso, será ainda mais danoso permitir que estes ainda dirijam prisões.

Há tempos em que não se admite que um particular coaja outrem com o uso da força, cabendo exclusivamente ao Estado assegurar a ordem pública. A vingança admitida pela Lei de Talião deixou de ser permitida, sendo que até mesmo o caráter retributivo da pena foi mascarado por pretensas funções de ressocialização e reeducação da pena.

É através da execução penal que o Estado realmente exerce seu poder de punir, tocando apenas a ele o uso da força para manter a segurança, sendo que a coerção é inerente à administração de instituições penais.

Ora, admitir-se-ia então que o particular que gerencia uma prisão mate um interno ao empreender uma força para evitar uma rebelião, ou mesmo para proteger outro detento?

Insta ainda salientar que o preso exerce na prisão um trabalho praticamente escravo, vez que tem uma remuneração irrisória, não tendo quaisquer direitos trabalhistas assegurados, não podendo sequer fazer greve para tentar garanti-los. $\mathrm{O}$ contrato de trabalho do interno não é realizado com qualquer espécie de acordo entre este e o presídio, que apenas the impõe o serviço que deverá exercer, e o detento o exerce sem questionar, pois é a única possibilidade de diminuir sua pena pela remição.

Logo, a remição acaba sendo utilizada como forma de opressão, pois além de garantir mão-de-obra barata, sem direitos trabalhistas, contém aqueles que trabalham, pois têm naquele trabalho forçado sua única chance de remir a pena.

Desta maneira, não há como delegar a um particular uma função sobre a qual o Estado deveria ter monopólio. Não se pode admitir que os detentos sejam utilizados como forma de obtenção de lucro, e não de recuperação, base da justificação da pena, não se podendo conceber que uma empresa adquira benefícios às custas do sofrimento e exploração dos detentos.

Não se pode afirmar, como pretendem aqueles que militam a favor da privatização, que o seu objetivo seria melhorar a situação calamitosa pela qual atravessa nosso sistema carcerário, incapaz de reintegrar seus internos ao meio social, gerando mais criminalidade, uma vez que, nem mesmo os objetivos que Ihe justificam 
são cumpridos, sendo que cenários de tortura, maus tratos, exploração e violência psíquica permanecem, em nada alterando a vida dos encarcerados, havendo até mesmo aqueles que solicitam retornar para as cadeias estatais. (FORTALEZA, 2001)

Tais dados vêm apenas comprovar que há um propósito meramente mercantilista na participação dos particulares na administração de presídios, que não se preocupam em reinserir seus internos na sociedade, posto que um detento ressocializado seria menos uma mão de obra a ser explorada. Assim, questiona-se se as empresas privadas teriam interesse em diminuir a reincidência, uma vez que o lucro é contabilizado pelo número de detentos, sendo que o simples fato dos particulares utilizarem as instituições penais para auferir lucro, já contrapõe qualquer característica de prevenção da pena.

Ora, haverá então interesse em se prender mais para garantir o crescimento da "indústria" do presídio, uma vez que o maior número de encarcerados indica mais mãode-obra, mais lucro.

o grande atrativo da administração privada das prisões e das companhias de serviços é simples: eles podem realizar nas prisões o mesmo trabalho feito pelo governo a um custo mais baixo, normalmente de $5 \%$ a $15 \%$ abaixo dos custos do setor público". E como isto é possível? Em detrimento dos salários dos empregados e no não investimento em serviços que poderia transformar os presos em membros produtivos da sociedade quando libertados, pois companhias preocupadas com os lucros preferem evitar os custos com tratamento para viciados, aconselhamento em grupo, programas de alfabetização. (SÃO PAULO, 2002, p. 28)

De tal modo, observou-se que as prisões privadas não apenas deixam de incentivar a educação, dando ênfase no trabalho como ocorre no atual sistema carcerário, como toda sua estrutura é baseada na exploração dos seus internos.

Portanto, o que se conclui é que o Estado não pode transferir uma parte de seu poder de polícia, delegando a manutenção da segurança pública a particulares, devendo o uso legítimo da força ser por ele monopolizada, sendo que o direito de privar um indivíduo de sua liberdade é uma das situações que justificam a sua própria existência.

Mas o que se procurou enfocar é que a privatização dos presídios é completamente contraditória à possibilidade de se admitir a remição pelo estudo, uma vez que tais presídios, como já supra-analisado, se sustentam e dão lucro pelo trabalho 
dos seus internos. Logo, se houver a possibilidade de remir a pena pelo estudo, e se todos os condenados optassem por esta forma de remição, tais presídios perderiam seu meio de subsistência.

Impossível então admitir uma espécie de presídio cuja base de sustentação está na exploração dos detentos, que se suprimida, extingue tais presídios.

Assim, é absurda qualquer pretensão de passar aos particulares a execução penal, a transformando em mero negócio capitalista, sujeita a abusos e desvios de poder ainda mais proeminentes dos já vivenciados em nossas instituições públicas, sendo que naquelas o caráter capitalista de acumulação e exploração, de necessidade de reprodução das desigualdades sociais é inquestionável, uma vez que, como entidade privada, o lucro é o fim que pretende alcançar.

\section{6 ÓCIO: “OFICINA DO DIABO?”}

Dentre as diversas justificativas que tentam legitimar a imposição do trabalho aos encarcerados, há sempre a afirmativa de que o "ócio é oficina do diabo", devendo a mente dos detentos ser ocupada a fim de impossibilitar que surja qualquer idéia tortuosa. De acordo com os adeptos de tal expressão, os internos se aproximariam do crime à medida que ficassem ociosos.

Cumpre salientar que o advento da revolução industrial impôs aos cidadãos das sociedades que a experimentava, uma incessante busca por capitais e bens, sendo que para alcançá-la aqueles que detinham os meios de produção passaram a forçar seus operários a trabalhar ininterruptamente, a fim de garantir sua crescente acumulação de riquezas, que Ihes permitia se manter e ascender em sua posição social.

Nessa realidade, o ócio foi repudiado de tal maneira que chegou a constituir crime o fato de nele permanecer. Descobriu-se que criminalizar os mendigos e "vagabundos" era um negócio amplamente vantajoso, uma vez que os mesmos poderiam ser utilizados como força de trabalho facilmente explorado e controlado pelo próprio Estado, tendo as penitenciárias se transformado em verdadeiro depósito de mão-de-obra desqualificada. Vale lembrar que a sociedade capitalista se caracteriza por dar preferência pela quantidade em vez da qualidade. 
A sociedade industrial fez com que os operários agissem somente com o corpo, impossibilitando-lhes a expressão com a mente, fazendo com que o seu cérebro se tornasse inútil, vez que sujeitados apenas a um trabalho 'braçal' e repetitivo, que não Ihes exigia qualquer esforço intelectual.

Nesse contexto, todas as instituições a nossa volta, que funcionam, assim como o Direito Penal, como forma de controle social, nos prepararam de uma forma obsessiva para trabalhar, repelindo qualquer forma de ócio, sendo tal fato reproduzido no cárcere, que é uma realidade industrial voltada para produção material.

Insta ainda salientar que a pena, tal como surgiu no direito canônico, era um isolamento para possibilitar a meditação e prece, visando à expiação dos pecados cometidos. Tem-se então que naquela época o ócio era utilizado como uma "oficina de Deus", uma forma de encontrá-Lo e se livrar do mal cometido. Entretanto, com o advento das necessidades da sociedade capitalista, o ócio passou a ser considerado "oficina do diabo", com o intuito impedir a cessação do trabalho, imprescindível para alcançar os objetivos desta sociedade, alcançados pela exploração da mão de obra.

Como então conceber que, para alguns, o ócio é meio para atingir superioridade intelectual ou uma forma de expiar os pecados, enquanto para outros, ocupantes de uma sociedade capitalista e mais precisamente aqueles que possuem condição sócio-econômica inferior, é banido por ser julgado maléfico, considerado como uma forma de incitar a criminalidade?

Assim, há uma contrariedade na forma de se lidar com o ócio, sendo que este não é permitido àqueles que pertencem aos estratos sociais inferiores, uma vez que o regime de servidão ao qual são submetidos é necessário para manter a sociedade capitalista em que vivemos. Tendo em vista que o trabalho operário, por eles exercido, não permite com que desenvolvam qualquer capacidade intelectual, sendo que, como já citado, não é interesse da classe hegemônica que aqueles que ocupam posição social desvantajosa se qualifiquem a ponto de ambicionar uma escala social. Primeiro porque temem ter sua posição privilegiada substituída, e ainda porque é necessário manter as desigualdades, fundamentais para que os operários permaneçam submissos e facilmente explorados. 
Desta forma, ainda que fosse verídica a expressão que o "ócio é oficina do diabo", assim como a mente dos detentos é "ocupada" pelo trabalho, o poderia ser pelo estudo. Entretanto, o que se observa é que o real motivo pelo qual o trabalho é infligido aos internos não é a ocupação de suas mentes com o intuito que se afastem da criminalidade, mas, ao contrário, pretende manter esta criminalidade e desigualdade, tão necessárias à sobrevivência do sistema capitalista.

Logo, o trabalho é instituído nas penitenciárias como forma de restringir a liberdade individual dos detentos, transformando-os em unidades numeradas em série, disciplinados e obedientes, se submetendo às normas ditadas pelo sistema capitalista, que os utiliza para aumentar sua produção e thes manter na classe social desfavorecida.

\section{CONCLUSÃO}

Concluiu-se neste estudo que a pena vem sendo utilizada como forma de manter a sociedade capitalista à medida que contém a classe subalterna, impedindo-a de qualquer ascensão social. Tendo em vista que a reprodução das desigualdades é indispensável para sobrevivência desta sociedade que se baseia na exploração e submissão de um homem pelo outro e, ainda, porque tem funcionado como reserva de mão de obra para a produção capitalista.

Insta ressaltar que o Direito Penal é uma das formas de controle social, sendo que o grupo dominante o utiliza para salvaguardar seus interesses capitalistas. Porém, para tanto, o Direito Penal, que se serve principalmente do cárcere para garantir os citados interesses, se intitula de pretensos propósitos ressocializadores para perseguir seus verdadeiros objetivos.

Nesse contexto surge a remição pelo trabalho, perfeita para satisfazer os preceitos capitalistas a que nos referimos, ou seja, manter a desigualdade social e garantir mão de obra, não tendo qualquer objetivo de cumprir a prevenção especial positiva a que se propõe. 
Assim, a possibilidade do condenado remir sua pena trabalhando é uma forma de incentivar que os detentos trabalhem, mantendo desta forma a citada reserva de mão-de-obra, fazendo com que surja uma estreita relação entre cárcere e fábrica.

Cumpre salientar que é de grande interesse para os detentores dos meios de produção que tal relação seja mantida, pois assim podem obter mão-de-obra barata e supervisionada, visto que os encarcerados são mantidos sob constante vigilância, tendo sua rotina totalmente controlada.

Nesse contexto, a remição só é concedida com base no trabalho, e não com base no estudo, pois o cárcere não pretende melhorar as condições do interno, mas apenas produzir mão de obra para as fábricas. Assim, àqueles que se sujeitam ao trabalho, o Estado beneficia com o instituto da remição, que não é concedido àqueles que desejam estudar para poder almejar uma ascensão social, objetivo que não apenas não visa o cárcere, sendo ainda por ele combatido.

Permitir a remição da pena pelo estudo seria uma forma de efetivar a função de prevenção especial positiva, hoje meramente utópica. Isto permitiria uma qualificação dos internos possibilitando-os almejar melhores condições de vida, diminuindo ainda a reincidência, tendo em vista que Ihes seria dado outra opção senão cometer delitos. Esta opção não Ihes é possível, pois além de serem estigmatizados pela condenação, ainda são desqualificados.

Entretanto, pelos fatos acima expostos, a remição da pena pelo estudo tem fins distintos daqueles almejados pela classe hegemônica, uma vez que tal forma de remição poderia gerar uma alteração na escala vertical da sociedade. $E$ ainda prejudicaria senão a melhor fonte de mão-de-obra, pelo menos a mais barata, não interessando à citada classe, não sendo, por isso, admitido.

Assim, as pretensões capitalistas são o único obstáculo para se aceitar a remição da pena pelo estudo. A remição pelo trabalho é aceita por ser nada mais do que um instrumento para alcançar os fins capitalistas, não tendo qualquer pretensão de reinserir o condenado na sociedade, sendo que a remição pelo estudo não é tolerada porque pretende concretizar uma real ressocialização do condenado.

Portanto, percebeu-se que a remição da pena pelo estudo não tem apenas caráter de política criminal, mas se propõe a um objetivo maior, fazer com que a pena 
abandone seu caráter retributivo e de ser meio para materializar os ideais capitalistas, únicos fins a que se tem prestado, para garantir, não apenas de maneira formal, a reinserção do condenado na sociedade, tendo em vista que a educação é uma forma de emancipar os detentos, de permitir que os mesmos possam realmente atingir a liberdade quando saírem da penitenciária.

Sendo assim, imperioso se faz a admissão do estudo como forma de remir a pena, uma vez que esta forma de remição possibilitaria a concretização de um Direito Penal mais justo, fazendo com que o ideal de uma função de prevenção especial positiva deixe de ser apenas uma ilusão utilizada para legitimar o uso da pena, sendo realmente consolidada.

\section{REFERÊNCIAS BIBLIOGRÁFICAS}

BARATTA, Alessandro. Criminologia Crítica e Crítica do Direito Penal. Introdução à Sociologia do Direito. 2. ed. Rio de Janeiro: Freitas Barros, 1999

BATISTA, Nilo. Introdução Crítica ao Direito Penal Brasileiro. 5. ed. Rio de Janeiro, Revan, 2001.

FERRAJOLI, Luigi. Direito e razão: Teoria do Garantismo Penal. São Paulo: Revista dos Tribunais. 2002.

FOUCAULT, Michel. Estratégia, poder saber. Rio de Janeiro: Forense Universitária, 2003.

FOUCAULT, Michel. Vigiar e Punir: nascimento da prisão. 23. ed. Petrópolis: Vozes, 2000.

FORTALEZA. Jornal O Povo, Fortaleza, 08 de agosto. 2001. Disponível em $<$ www.noolhar.com.br/opovo/fortaleza/27756.html> acessado em 03/02/2005.

MOREIRA, Rômulo de Andrade. A privatização das prisões. Disponível em $<$ www.bu.ufsc.br/privatização.html> acessado em 15/03/2005.

NETO, Eduardo Araújo. Aspectos sobre a privatização dos presídios no Brasil. Disponível em $<$ <ww.pgj.ce.gov.br/artigos/artigo76.htm> acessado em 15/03/2005.

PRADO, Luis Regis. Curso de Direito Penal Brasileiro: parte geral. 2. ed. São Paulo: Revista dos Tribunais, 2000.

REVISTA do Conselho Nacional de Política Criminal e Penitenciária. v. 1, n. 5, 1995-1993 - semestral. Remição da pena. Parecer do Conselheiros Luiz Alfredo Palm, 188-189, Brasília.

RUSCHE, George; KIRCHHEIMER, Otto. Punição e estrutura social. 2. ed. Rio de Janeiro: Freitas Bastos, 1999. 
SANTOS, Juarez Cirino. A criminologia radical. Rio: Forense, 1981.

SÃO PAULO. Jornal O Estado de São Paulo, São Paulo: 2001. Disponível em

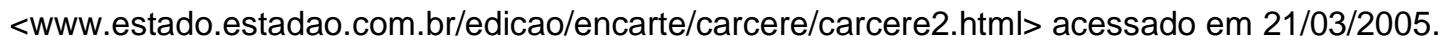

SÃO PAULO. Revista Brasileira de ciências criminais. São Paulo: Editora Revista dos Tribunais, 2002.

ZAFFARONI, E. Raul; BATISTA, Nilo. Direito Penal Brasileiro - I. 2. ed. Rio de Janeiro: Revan, 2003. 660 . 